\title{
Law on Control of Marine Environmental Pollution in Vietnam Today: Assessment of Content and Proposing Solution to Further Complete the Law
}

\author{
Luan Nguyen Thanh* \\ Division 871, General Political Department, Ministry of Defence, 676 Nguyen Van Cu street, Long Bien District, \\ Hanoi City, Socialist Republic of Vietnam. \\ *Corresponding author. Email: thanhluanbdbp@gmail.com.
}

\begin{abstract}
ABTRACT
This study focuses on analyzing the content of the current law on controlling the marine pollution in Vietnam. These regulations are mainly under the Law on Environmental Protection 2014; Law on Natural Resources and Environment of Sea and Islands 2015 and documents guiding to implement these two laws. In general, the law on control of marine environmental pollution consists of two groups of provisions: a group of regulations on prevention of marine environmental pollution and a group of provisions on overcoming marine environmental pollution. The practice of implementing these regulations is still inadequate, thus leading to serious environmental pollution in Vietnam. In order to control the pollution of Vietnam's marine environment, it is necessary to amend and supplement the provisions of the law on control of marine environmental pollution and implement measures to improve the efficiency of law enforcement in this field.
\end{abstract}

Keywords: Control of environmental pollution; Environmental pollution; Marine environmental pollution.

\section{INTRODUCTION}

Vietnam is a coastal country with a length of 3,260 $\mathrm{km}$ located on the west coast of the Pacific Ocean. This is a strategic position in terms of geopolitical, economic, marine arteries of the world, connecting the Pacific Ocean and Indian Ocean; Americas with Asia; Europe, the Middle East with Asia and among Asian countries [1]. The sea brings a lot of benefits to Vietnam for economic and social development such as marine life resources, petroleum resources, marine tourism resources, marine energy resources (waves, sea breeze)... According to statistics, at present, in Vietnam, the sea economic sectors account for about $10 \%$ of the national GDP; The economy of 28 coastal provinces and cities is estimated to reach $65-70 \%$ of the national GDP. In coastal provinces and cities, human development index is higher than the national average; The average income per capita is 1.2 times or more compared to the national average income ... [2]. However, in recent years, the situation of marine environmental pollution has been very serious, which negatively affects people's lives and the sustainable development of the marine economy. For example, for incidents of pollution of the marine environment due to the discharge of waste from Vung Ang and Ha Tinh industrial parks of Formosa Group in 2016. According to a Government report, the economic and social losses is huge, thus affects the long-term livelihood of people in coastal areas: more than 17,600 fishing boats and nearly 41,000 people have been directly affected; More than 176,000 dependents were affected. The coastal fishing output has lost about 1,600 tons/month... [3]. Currently, Vietnam has many regulations to control pollution of the marine environment. However, there are still some unclear regulations that make it difficult to enforce. In addition, Vietnam still lacks human resources, science and technology to effectively implement activities to control marine environmental pollution. Therefore, the research to improve the law on control of marine pollution and improve the efficiency of enforcement is really necessary and will be presented in this article. 


\section{ASSESSMENT OF THE CURRENT LAW ON THE CONTROL OF MARINE POLLUTION IN VIETNAM TODAY}

According to Article 3.18 of Law on Environmental Protection 2014: "Pollution control refers to the process for preventing, detecting, controlling and removal of pollutants or contaminants". From this regulation, it can be seen that controlling marine environmental pollution is an activity to control environmental pollution in a specific field. Controlling marine environmental pollution is the activity of state agencies and other individuals and organizations in society. The law on the control of marine environmental pollution is a combination of legal regulations promulgated by competent state agencies to prevent, detect, and handle of pollution. Regulations of law on control of marine environmental pollution include of the following two main groups:

Group 1: Regulations to prevent pollution of the marine environment.

Group 2: Regulations to overcome (detect, prevent and handle) pollution of the marine environment.

In fact, the division of legal regulations on the control of marine environmental pollution into the two groups above is only relative. Because there are regulations that are both preventive and corrective for pollution of the marine environment.

Currently, in Vietnam, the law on control of marine environmental pollution includes the following specific provisions:

Firstly, regulations to prevent pollution of the marine environment

Regulations aimed at attracting environmentally friendly investment projects in coastal areas.

Law on Environmental Protection 2014 and Law on Natural Resources, Environment of Sea and Islands 2015 all identify the principle of prevention is the key in controlling environmental pollution in general and marine environment in particular. In the Vietnam Sustainable Development Strategy for the period of 2011-2020, the Decision No. 432/QD-TTg also identifies one of the important goals, which is: "Sustainable industrial development with industry structure, technology and equipment to ensure environmentally friendly principles; actively preventing and handling industrial pollution, building a "green industry", giving priority to developing environmentally friendly industries, technologies and products, promoting high-tech development in urban areas, big towns. Step by step developing the environmental industry". With such guidelines, the sustainable development of coastal manufacturing industries is necessary. However, up to now, Vietnam has not had a list of environmentally friendly industries that need to be attracted in the coastal area. Therefore, many production and business establishments with industries that are at high risk of causing environmental pollution, along with irresponsibility in environmental protection, have seriously polluted the coastal areas. Typically, the case of Formosa Group caused incidents of Vietnam's central marine environment.

Regulations on the assessment of environmental impact.

Production and business establishments must carry out environmental impact assessment in order to forecast in advance the risks that may cause to the environment and based on that, propose solutions to minimize and eliminate the possibility of causing environmental pollution. Owners of coastal production and business establishments must also perform this obligation. Regulations on environmental impact assessment are stipulated in the Law on Environmental Protection 2014; Decree No. 18/2015/ND-CP dated February 14, 2015 on environmental protection planning, strategic environmental assessment, environmental impact assessment and environmental protection plans; Decree No. 40/2019/ND-CP. It can be seen that the current laws on environmental impact assessment in Vietnam are relatively complete. This is an important legal basis for environmental protection for coastal production and business entities to implement [4]. However, the reality of assessing coastal environmental impacts is much more difficult than in other areas. The assessment of the abilitity to cause damage to the marine environment by investment projects requires modern, scientific and technological equipment and a team of qualified officials. At present in Vietnam, there is a lack of science and technology in this area.

Regulations on general monitoring and supervision of natural resources and environment.

Article 3.10 Law on Natural Resources, Environment of Sea and Islands, 2015 has stipultaed: "General monitoring and supervision of natural resources and environment mean a process of monitoring natural resources and environment, and impacts on natural resources and environment in a systematical way to supply information for assessment of current conditions and development of natural resources and environment, making forecasts and warnings about negative impacts on natural resources and environment.". This is an activity of the competent state agency to regularly update information on marine environmental quality from which to give timely management solutions. However, this activity has not been really effective because Vietnam still lacks human resources, finance, and science and technology. The slow environmental information provided makes it very difficult for the control of marine environmental 
pollution. That is also the reason leading to the fact that many production and business establishments pollute the marine environment for a very long time that the competent state agencies cannot detect.

Regulations on public consultation when implementing coastal investment projects.

The Law on Environmental Protection 2014 provides for communities to participate in the process of environmental protection in general and the control of marine environmental pollution in particular. Specifically, in Article 21.2, project owners are obliged to consult with regulatory agencies, organizations and communities that are directly affected by the project when conducting report of environmental impact assessment. However, this provision is difficult to implement in practice. What is the definition of an agency, organization or community which are directly affected by the project? How many percentage of agreement must be reached so that the project owner can implement the project? Besides, Article 146.1 of the Law also provides: "Representatives of local communities bear the environmental impact of the production facilities, business services, have the right to request the home base business, production, services providing information on the protection of the environment through direct dialogue or in writing; the organization learn the reality about the environmental protection work of the production base, sales, service; collect, provide information to the competent authority and take responsibility for the information provided". This provision is not easily to be implemented in practice because the concept of community representatives has not been clarified. Whether this rule exclude the right to request information of individuals and organizations which are directly affected by the projects or not?

Secondly, regulations aimed at overcoming (detecting, preventing and handling) pollution of the marine environment

Environmental technical standards greatly serve the control of marine environmental pollution. This is the basis to determine whether the marine environment is polluted or not. Two groups of marine environmental technical regulations include: Environmental technical regulations with sea water and Technical regulations on waste and waste water that is discharged into the sea. In 2015, Vietnam had a National Regulation on sea water quality to assess and control sea water quality of the sea areas, serving the purposes of sports, aquatic recreation, aquaculture, protection of marine environment and other purposes; National standards on waste management to effectively control marine pollution [5]. However, in fact, many national standards on waste and waste water into the sea were issued more than a dozen years ago. For example: National technical regulation on coastal sea water quality; National technical regulation on industrial waste water from seafood processing ... [6]. It can be seen that these technical regulations are no longer conform to international standards and regulations and do not meet the requirements to the control of marine environmental pollution.

Provisions on handling of violations, overcoming pollution, compensating for damage when marine environmental pollution occurs.

First of all, organizations and individuals that commit acts of violating the legislation on control of marine environmental pollution may be examined for penal liability and sanction of administrative violations. If causing damage, they must pay compensation and take responsibility to overcome pollution [7].

The provisions on penal liability prosecution have been stipulated in the Penal Code 1999 and now the Criminal Code 2015 (amended and supplemented in 2017) has many amendments to this provision. However, up to now, there have been no cases in which environmental polluters have criminal responsibility in Vietnam. Regarding administrative responsibilities, organizations and individuals that cause marine environmental pollution may be sanctioned for administrative violations according to Decree No. $155 / 2016 /$ ND-CP. The highest administrative fine is VND 2 billion for organizations and VND 1 billion for individuals. In addition, organizations and individuals polluting the marine environment may also be deprived of the right to use licenses or suspend operation for a definite time (up to 24 months), and confiscate material evidences used for violations. However, the biggest difficulty is still the work of detecting violations of the law on control of marine environmental pollution. Many organizations and individuals stealthily dump waste into the sea. In particular, there are cases where businesses take advantage of rain to open sewage pipes mixed with rain water. Pollution of the sea environment is difficult to detect because it takes a long time and a large amount of waste to stink, creating a black area. Until the competent government finds out, the consequences are often very serious. In addition, proving the violation is very difficult because the same sea area has many entities discharging together or due to proving the violation, it must apply complex science and technology.

Any organization or individual violating the law on marine pollution control, if causing damage, must pay compensation in accordance with Decree No. 03/2015/ND-CP. However, in Vietnam today, if only applied according to common civil procedures, it is very difficult for the subject of damage because they are difficult to prove the damage and the causal relationship between violations and consequences. The practice of application of regulations on claim for damages in the field of environment in Vietnam shows that there must 
always have the intervention of state management agencies. It seems that Vietnamese authorities are administrating a civil relationship. Hence, it can be assessed that Vietnam has not had an appropriate mechanism in claiming damages in the field of environmental protection.

Regulations on responsibilities of state agencies in controlling marine environmental pollution.

According to current law, there are many entities involved in controlling marine pollution, including central and local authorities, common authorities and competent authorities, which are: Government, People's Committees at all levels, Ministry of Natural Resources and Environment, Department of Natural Resources and Environment, Division of Natural Resources and Environment, officers in charge of environment at commune level, other ministries and ministerial agencies... Despite the participation of many agencies, the control of marine environmental pollution in recent years still faces many shortcomings. This proves that the activities of competent state agencies are not really effective. In particular, Vietnam has no specific regulations on the responsibilities of state management agencies when pollution of marine environment occurs. Therefore, Vietnam's competent state agencies are still neglecting the management and control of marine environmental pollution [8].

\section{SOME SOLUTIONS TO IMPROVE THE LAW ON THE CONTROL OF THE MARINE ENVIRONMENTAL POLLUTION AND THE IMPLEMENTATION OF THIS LAW IN PRACTICE}

In order to improve the law provisions on the control of marine environmental pollution and the effectiveness of these regulations in practice, Vietnam needs to implement the following solutions:

The Government should soon develop a list of investment projects to encourage investment in coastal areas. These projects must be environmentally friendly. Investment project owners enjoy preferences according to the provisions of law on investment preferences. In addition, each locality also needs to have a list of environmentally sensitive marine areas such as aquaculture areas, beaches, tourist areas, protective forest areas ... so as not to allow projects with high risk of causing pollution investing into this area.

Completing regulations on community participation in controlling marine environmental pollution. Accordingly, the law should clarify the following contents:

The stages where people are involved in controlling marine environmental pollution. From the author's point of view, people are involved in every stage of marine environmental pollution control. Which is, right from the time the investor prepares the project, people have the right to express their opinions about whether or not they agree to implement the project. During the operation of the project, the people have the right to supervise the investors' performance of their obligations to protect the marine environment;

Determine who can give opinion. From the author's point of view, it is necessary to specify the conditions of participants expressing their agreement or disagreement about the implementation of investment projects: People with full capacity for civil acts; Residents at a radius of $3 \mathrm{~km}$ for an environmentally friendly project, $5 \mathrm{~km}$ for a project with high environmental pollution risk. The figure of $3 \mathrm{~km}, 5 \mathrm{~km}$ is according to the author's senses, the state needs the advice of environmental experts to give more scientific figures.

Clarify the concept of "Representative of the community', In the author's view, community representative is a group of people nominated by the community to represent the community in environmental relations. Community representatives are not competent state agencies. The opinion of the representative of a community does not exclude the opinion of every individual in that community.

Competent state agencies should soon develop and publish technical standards on sea water and waste water and garbage that are discharged into the sea. These technical regulations need to access to international standards and regulations and meet the needs of controlling marine environmental pollution.

Vietnam needs to develop a separate legal procedure for instituting an environmental dispute. Accordingly, there are many contents of the proceedings in the field of environment which will be different from ordinary civil procedures. The establishment of this procedural mechanism is based on the following basic principles: Principles of public intervention; Principles of expert consultation; Principles of support and cooperation; Principles of paying penalty for pollution from the polluters; Principles of prevention.

Completing regulations on responsibilities of state management agencies when marine environmental pollution occurs. This responsibility is primarily defined for local state management agencies because this is the direct management entity and often have the earliest information on the pollution of the marine environment. The content of environmental pollution management in general and marine environmental pollution in particular are criteria to determine the people's confidence level with management entities.

There should be a plan for scientific and technological development to apply to activities of controlling marine environmental pollution. 
Accordingly, Vietnam can implement the following roadmap: Step 1: Import science and technology from developed countries to serve activities to control marine environmental pollution; Step 2: Actively encourage to develop domestic science and technology towards proactive in technology of controlling marine pollution.

Training human resources for activities of controlling marine environmental pollution. Currently, officials in charge of marine environmental pollution control are mainly concurrent. In order to ensure the quality of cotrolling marine environmental pollution, each province or city directly under the central government needs to train a group of officials specialized in this field. Vietnam can cooperate with countries that have successfully controlled marine environmental pollution to send officials there to study or have their experts come to teach and impart experience.

\section{RESEARCH RESULTS}

This article has analyzed, fully assessed the laws on the control of marine environmental pollution and current practices in Vietnam. The article also proposed some valuable solutions to further complete the laws on the control of marine environmental pollution and some solutions to improve the efficiency when implementing the laws on the control of marine environmental pollution in Vietnam.

\section{CONCLUSION}

Controlling of marine pollution plays a huge role in Vietnam's sustainable marine economic development strategy. Currently, the law has many provisions governing this activity. However, the pollution of the marine environment still occurs in many places and the consequences are very serious. The main causes are identified as some of the legal provisions in this area are still missing, inadequate and contradictory. Besides, in many places, the competent state agencies are still loose in management and lack of specialized officials in this field. Science and technology have not yet met the needs of controlling marine environmental pollution. Technical standards on sea water, waste water and garbage discharged to the sea are outdated, which do not meet the practical needs. Vietnam still lacks a special procedural mechanism for initiating environmental disputes. Hence, in order to operate effective marine environmental pollution control, Vietnam needs to resolve the above difficulties and contradictions. Any solution needs to be concerned enough to achieve the best results.

\section{REFERENCES}

[1] B. Quang Dung, N. Hung Khanh, (2016), Tính toán chiều dài đường bò biển của Việt Nam (phần luc địa) dưa trên hệ thống bản đồ địa hình toàn quốc tỷ lệ 1/50.000 [Calculation of Vietnam's coastline length (continental part) based on a national topographic map, scale of the map is 1/50,000], Journal of Marine Science and Technology, Vol. 16, No. 03.

[2] A. Duong (2019), Các ngành kinh tế thuần biển đóng góp 10\% GDP cả nước, Báo Hà Nội Mói điện tú [The pure sea economic sectors contribute $10 \%$ of the country's GDP, New Hanoi Electronic Newspaper], available at $<$ http://www.hanoimoi.com.vn/tin-tuc/Kinhte/930382/cac-nganh-kinh-te-thuan-bien-dong-gop10-gdp-ca-nuoc > (accessed 26 March 2019)

[3] D. Trung Tu, P. Thi Ha (2019), Ô nhiếm môi truòng biển Việt Nam: Thưc trạng và khuyến nghị, Hội thảo "Đánh giá nhũng yếu tố tác động đến nhiệm vu bảo đảm an ninh trật tụ các tỉnh, thành ven biển góp phần phục vu chiến luợc phát triển bền vĩng kinh tế biển Việt Nam" [Pollution of Vietnam's marine environment: Current situation and recommendations, Workshop "Evaluation of factors affecting the task of ensuring security in coastal provinces and cities to contribute to the strategy of sustainable development in Vietnam's maritime economy'], Public Security Institute of Strategy and Science, Ministry of Public Security, June 2019.

[4] D. Hong Nhung, (2019), Pháp luật về bảo vệ môi truờng làng nghề ${ }^{\circ}$ Việt Nam [Laws on environmental protection of craft villages in Vietnam], Monograph, Hanoi National University Publishing House.

[5] Circular No. 67/2015/TT-BTNMT, dated 21/12/2015 of Minister of Ministry of Natural Resources and Environment of Socialist Republic of Vietnam on introduction of national technical regulation on environment.

[6] Decision No.16/2008/QĐ-BTNMT, dated $31 / 12 / 2018$ of Minister of Ministry of Natural Resources and Environment of Socialist Republic of Vietnam on introduction of national regulation on environment.

[7] Law on Environmental Protection, dated 23/06/2014 of Socialist Republic of Vietnam.

[8] L. T. Phuong Thao (2019), Giải pháp bảo vệ môi truờng biển ở nước ta hiện nay [Solutions to protect the marine environment in our country today], Journal of Education and Social Affairs, Special edition October 2019. 